\title{
Bioherbicidal activity of Eruca sativa fresh shoot aqueous extract for the management of two annual weeds associating Pisum sativum plants
}

\author{
Mona Adel El-Wakeel* ${ }^{*}$, Ebrahim Roushdi El-Desoki and Salah El-Din Abd El-Ghany Ahmed
}

\begin{abstract}
Background: Brassica species have been established to have very high concentrations of glucosinolates, flavonols, and other secondary metabolites that achieved good results in weed management strategy. So, this study highlights how to investigate the allelopathic potential of Eruca sativa fresh shoot aqueous extract as a natural bioherbicide to control Phalaris minor and Beta vulgaris weeds beside its effect on Pisum sativum growth as well as yield traits. Two pot experiments were conducted in the greenhouse of the National Research Centre, Dokki, Giza, Egypt, in the two successive winter seasons of (2016-2017, 2017-2018). Treatments were applied by spraying $E$. sativa fresh shoot aqueous extract once at 14 days after sowing and twice at 14 and 21 days after sowing at rates of $20,40,60$, and $80 \% \mathrm{w} / \mathrm{V}$.
\end{abstract}

Results: E. sativa fresh shoot aqueous extract at $80 \%$ achieved the maximum inhibition effect on the growth of both weeds. This in turn was reflected on $P$. sativum plant and gave the observable highest growth and yield parameters. Chemical analysis of E. sativa shoot powder approved the presence glucosinolates $(9.6 \mu \mathrm{mol} / \mathrm{g})$ and phenolic compounds $(46.5 \mathrm{mg} / \mathrm{g})$ which may be responsible for the allelopathic effect.

Conclusion: Spraying of aqueous fresh shoot extract of E. sativa at $80 \%(w / V)$ can be applied as natural selective bioherbicide in controlling the two annual grassy and broad-leaved weeds associated with P. sativum plants.

Keywords: Allelopathy, Eruca sativa, Pisum sativum, Glucosinolates, Phenolic compounds

\section{Background}

Pea (Pisum sativum) is one of the important grain legumes that grow in various parts of the world. Several types of weeds are associated with $P$. sativum. Weeds can reduce grain yield as well as quality through direct competition on nutrients, moisture, space, and light (Wu et al. 2000). On an average, weeds cause a depression in crop productivity that reaches to $34 \%$ (Oerke 2006). Many cultural, mechanical, chemical, and biological methods were applied for controlling weeds. Hand weeding is a useful method, but is time-consuming and costs. Although the application of chemical herbicides is effective in controlling weeds, it results to a negative impact on human and

\footnotetext{
* Correspondence: m.elwakeel2000@yahoo.com

Botany Department, Agicultural and Biological Division, National Research Centre, P.O. Box 12622, Giza, Egypt
}

(c) The Author(s). 2019 Open Access This article is distributed under the terms of the Creative Commons Attribution 4.0 International License (http://creativecommons.org/licenses/by/4.0/), which permits unrestricted use, distribution, and reproduction in any medium, provided you give appropriate credit to the original author(s) and the source, provide a link to the Creative Commons license, and indicate if changes were made. animal (Vyvyan 2002). Moreover, widespread use of herbicides causes soil and groundwater pollution, and toxic residues that accumulate in agricultural products and weeds become resistant to these herbicides (Jabran et al. 2015). More than 471 weed species are documented to have a resistance to commonly used chemical herbicides such as those in triazolopyrimidine sulfonanilide, sulfonylurea, and theimidazolinone families. Recently, allelopathic potential of plants are getting much interest to face all these problems in controlling weeds (Jabran et al. 2015; El-Rokiek et al. 2018 and El-Dabaa et al. 2019).

Allelopathy is a biological phenomenon by which the plant (including microorganisms) produces biochemicals that influence the germination and growth of other plant. These biochemicals (allelochemicals) may have beneficial or harmful effect on the target plant (Reigosa

\section{Springer Open}


et al. 2006). Modern phytochemical methods of extraction, isolation, purification, and identification have contributed to identify these allelochemicals which can be classified in various ways (Ferreira and Áquila 2000). Manipulation of natural products extracted from plants is a healthy and eco-friendly approach to control the weeds (Khan et al. 2007).

Eruca sativa Mill. (commonly known as Rocket salad) belongs to family Brassicaceae. E. sativa is a good source of vitamin $C$ and antioxidants such as phenolic compounds, carotenoids, glucosinolates, and degradation products as isothiocyanates (Martinez-Sanchez et al. 2008; Villatoro-Pulido et al. 2012; Martinez-Ballesta et al. 2013; Messiha et al. 2013; Ahmed et al. 2014; El-Masry et al. 2015). Glucosinolates (GSLs) are sequestered in the vacuoles of Brassicaceae plants only (Daxenbichler et al. 1991). As Brassicaceae plant tissues are damaged, GSLs are hydrolyzed by myrosinase enzyme (present at high levels in myrosin cells) (Bones and Rossiter 2006). GSLs are hydrolyzed to glucose and unstable intermediate. This intermediate degrades to various products including thiocyanates, isothiocyanates, and nitriles. The produced hydrolyzed products are dependent on the glucosinolate itself and the conditions of the reaction (Fahey et al. 2001).

The identified GSLs in Rocket seeds are glucoerucin (4-methyl-thiobutylglucosinolate) and low levels of glucoraphanin (4-methyl-sulphinylbutylglucosinolate) (Ori et al. 1999; Bennett et al. 2006), whereas the major identified GSL in Rocket leaves is glucosativin (4-mercaptobutylglucosinolate) (Bennett et al. 2002). Glucoerucin is the precursor of erucin (4-methyl-thiobutylisothiocyanate) (Bennett et al. 2007). Moreover, sulforaphane (4-methyl-sulfi-nylbutylisothiocyanate) is derived from glucoraphanin. Sulforaphane is one of the most known natural anti-cancer isothiocyanate compounds and is identified in Rocket species (Bonnessen et al. 2001; Smith 2001 and Zhang 2004). Additionally, sativin (4-mercaptobutyl-isothiocyanate) is derived by hydrolysis of glucosativin. Sativin is a pungent volatile compound which may be responsible for $E$. sativa distinct odor (Bennett et al. 2002). Bennett et al. 2007 found that erucin and sativin are significantly biologically active isothiocyanates in Rocket species.

\section{Material and methods}

\section{Preparation of water extract}

Eruca sativa (Rocket salad) shoots were collected from Egyptian fields and washed with tap water then cut into small particles. Stock solution $(80 \% w / v)$ was prepared according to Fuentes et al. 2012. Eight hundred grams of E. sativa fresh shoots was soaked in $1 \mathrm{~L}$ of distilled water then mixed well using an electric ground blender. The produced mixture transferred to a $2-\mathrm{L}$ beaker and covered with parafilm. The beaker was placed on a shaker (200 revolution/min) for $48 \mathrm{~h}$ at room temperature. The mixture was filtered through four layers of cheesecloth to remove debris and centrifuged for $30 \mathrm{~min}$. The supernatant was then filtered through one layer of filter paper (Whatman No. 1). Three concentrations 20,40 , and $60 \%(w / v)$ were prepared by dilution of $80 \%$ crude extract using distilled water. The method of extraction was repeated according to need that the extracts were always fresh.

\section{Experimental procedure}

Two pot experiments were applied in November during two successive winter seasons (2016-2017) and (20172018) in the greenhouse of the National Research Centre (NRC). Both experiments were performed in a completely randomized design with nine replicates. Pottery pots (30 $\mathrm{cm}$ in diameter and $0.07 \mathrm{~m}^{2}$ in area) were filled with equal amounts of sieved sandy-loam soil (4Kg soil/pot). Seeds of Pisum sativum (Pea) (cv. MasterB) were obtained from The Agricultural Research Centre, Egypt. Five seeds of $P$. sativum were sown $2 \mathrm{~cm}$ deep from the soil surface. All pots (except the healthy treatment [P. sativum only]) were infested with the same weight $(0.5 \mathrm{~g} / \mathrm{pot})$ of Phalaris minor (littleseed canarygrass) and Beta vulgaris (chard) weed seeds and mixed well. Ten treatments were applied in this study. Four treatments were sprayed once at 14 days after sowing (DAS) with $E$. sativa fresh shoot aqueous extracts $(20,40,60$, and 80 (crude extract)). The corresponding four treatments were sprayed twice at 14 and 21 DAS (seedlings were at 4 leaf stage) with the E. sativa fresh shoot aqueous extracts at the same concentrations. Additionally, healthy and infested untreated control treatments were sprayed with tap water for comparison. Both extracts and tap water were sprayed using a hand sprayer at the rate of $50 \mathrm{ml} /$ pot on foliage part of $P$. sativum and its associated weeds ( $P$. minor and $B$. vulgaris). All treatments were maintained under greenhouse condition, and all cultural practices of irrigation and fertilization were applied.

\section{Studied parameters \\ Weeds}

In both seasons, weeds under study were collected from three replicates of each applied treatment at 45 and 70 DAS. The dry weight (g/pot) of separated weeds was determined after drying in a forced draft oven at $70^{\circ} \mathrm{C}$ for $48 \mathrm{~h}$.

\section{Pisum sativum plants}

Growth parameters In both seasons at 45 and 70 DAS, $P$. sativum plants were collected from three replicates of each treatment to determine shoot height/plant $(\mathrm{cm})$, 
number of leaves/plant, number of branches/plant, and dry weight of plant (g).

Yield and yield attributes At harvest, samples of $P$. sativum plants were taken from each treatment to determine number of pods/plant, dry weight of pods/plant (g), number of seeds/plant, and dry weight of seeds/ plant.

\section{Chemical analysis of E. sativa shoots powder}

Total glucosinolates (GSLs) ( $\mu \mathrm{mol} / \mathrm{g} \mathrm{DW})$ were extracted from $E$. sativa dry shoot powder. GSLs were measured by determining the liberated glucose which was released during hydrolysis by the myrosinase enzyme (Rauchberger et al. 1979). The resulting glucose was determined colorimetrically according to the methods defined by Nasirullah and Krishnamurthy (1996). The GSLs value was obtained by multiplying the factor 2.1 for glucose.

Total phenolic contents (mg/g DW) were determined in E. sativa dry shoot powder colorimetrically using Folin and Ciocalteu phenol reagent according to the method defined by Snell and Snell (1953) (Table 1).

\section{Statistical analysis}

Since the homogeneity test proved the homogeneity and normality of the data of the two seasons, combined analysis was performed. All obtained data were subjected to proper statistical of variance according to Snedecor and Cochran (1980). The mean values were compared using Duncan's multiple range test (Duncan 1955) at 5\% level of probability.

\section{Results}

\section{Weed growth parameters}

Results presented in Table 2 revealed that the dry weights of both weeds, i.e., P. minor and B. vulgaris, were significantly reduced by spraying of $E$. sativa fresh shoot aqueous extract. Once or twice spraying of $E$. sativa fresh shoot aqueous extract at different concentrations (20,40,60, and $80 \%)$ affected on dry weight of both weeds as compared to the unweeded treatment at 45 and 70 DAS.

Treatment of spraying $80 \%$ twice recorded the highest reduction in dry weight of the grassy weed followed by $60 \%$ twice and $80 \%$ once in both samples. The reduction amounted to $80.80,69.95$, and 65.59 at the first sample, whereas $68.27,60.41$ and $59.48 \%$ at the second sample, respectively, when compared to unweeded treatment (control). With regard to broad-leaved weed, the results in Table 2 also cleared that B. vulgaris was affected in the same trend as grass weed. The reduction amounted to $84.66,76.43$, and $75.41 \%$ at the first sample and reached to $72.73,68.87$ and $61.39 \%$, respectively at the second sample as compared to control treatment.

\section{Pisum sativum plants Growth parameters}

As shown in Table 3, most of the applied concentrations of $E$. sativa fresh shoot aqueous extract, sprayed either once or twice, had a significant effect on most growth parameters under study, i.e., shoot height, number of leaves/plan, number of branches/plant, and dry weight of plant. At 45 and 70 DAS, healthy plants and spraying $80 \%$ twice recorded the highest growth parameters, with no significant difference between them in most parameters. Treatments of spraying $60 \%$ twice and $80 \%$ once followed these ideal treatments, also with no significant difference between them in most parameters, as compared to the other treatments. The increases in plant dry weight at the first sample reached to $112.09,109.89$, 108.79 , and $83.52 \%$. Whereas in the second sample, the increment percentage reached to $235.19,201.85,182.10$, and $153.70 \%$, respectively, as compared to untreated plants (control). It is clearly observed that the twice spray of E. sativa water extract induced the growth parameters of $P$. sativum than once spray treatments. Additionally, there is a direct relationship between concentration of extract and increment in growth parameters. Conversely, the unweeded treatment recorded the lowest values in all growth parameters of $P$. sativum plants at both ages.

\section{Yield and yield attributes}

Results in Table 4 revealed that most of the applied weed control treatments caused a significant progress in yield and its attributes, i.e., number of pods/plant, dry weight of pods/plant, number of seeds/plant, and dry weight of seeds/plant. Weed free, 80 and 60\% twice spray treatments provided the maximum values of yield and its attributes. These mentioned superior treatments were followed by $80 \%$ once spray except in the case of number of pods/plants that $40 \%$ twice spray came in the fourth rank. Generally, it is worthy to mention that twice spay of E. sativa fresh aqueous extract provided a higher yield progress than once spray. Moreover, the increment in extract concentration is accompanied with high yield production. So, $80 \%$ twice spray of $E$. sativa fresh aqueous extract

Table 1 Total glucosinolates ( $\mu \mathrm{mol} / \mathrm{g}$ DW) and total phenolic contents (mg/g DW) in E. sativa shoot powder

\begin{tabular}{lcc}
\hline Material & Total GSLs $(\mu \mathrm{mol} / \mathrm{g} \mathrm{DW})$ & Total phenolic compounds $(\mathrm{mg} / \mathrm{g}$ DW) \\
\hline Eruca sativa shoot powder & 9.55 & 46.5 \\
\hline
\end{tabular}


Table 2 Effect of spraying different concentrations of E. sativa fresh aqueous extract on dry weight of $P$. minor and B. vulgaris (g/ pot). (Combined analysis of the two seasons)

\begin{tabular}{|c|c|c|c|c|c|c|}
\hline \multirow[t]{3}{*}{ Treatments } & & \multirow{2}{*}{\multicolumn{2}{|c|}{$\frac{\text { First sample }}{\text { Dry weight (g/pot) }}$}} & \multicolumn{2}{|c|}{ Second sample } \\
\hline & & & & & \multirow[b]{2}{*}{ P. minor } & \multirow[b]{2}{*}{ B. vulgari } \\
\hline & \multicolumn{2}{|c|}{$\begin{array}{l}\text { E. sativa fresh aqueous } \\
\text { extract concentration (\%) }\end{array}$} & P. minor & B. vulgaris & & \\
\hline P. sativum only & 0 & & $0.00 \mathrm{a}$ & $0.00 \mathrm{a}$ & $0.00 \mathrm{a}$ & $0.00 \mathrm{a}$ \\
\hline P. sativum + P. minor $+B$. vulgaris & 0 & & $8.02 \mathrm{~h}$ & $7.89 \mathrm{f}$ & $10.81 \mathrm{f}$ & $8.03 \mathrm{f}$ \\
\hline \multirow[t]{4}{*}{ P. sativum + P. minor $+B$. vulgaris + E. sativa } & Once spray & 20 & $6.78 \mathrm{~g}$ & $6.72 f$ & $9.24 \mathrm{e}$ & 7.64 ef \\
\hline & & 40 & $5.74 f$ & $3.35 \mathrm{de}$ & 8.37 de & $5.30 \mathrm{~cd}$ \\
\hline & & 60 & $3.65 \mathrm{de}$ & $2.52 \mathrm{~cd}$ & $6.70 \mathrm{c}$ & $3.88 \mathrm{bc}$ \\
\hline & & 80 & $2.76 \mathrm{~cd}$ & $1.94 \mathrm{bc}$ & $4.38 \mathrm{~b}$ & $3.10 \mathrm{~b}$ \\
\hline \multirow[t]{4}{*}{ P. sativum + P. minor $+B$. vulgaris $+E$. sativa } & Twice & 20 & 4.62 e & $4.36 \mathrm{e}$ & $7.25 \mathrm{~cd}$ & $5.93 \mathrm{de}$ \\
\hline & & 40 & $3.44 \mathrm{~cd}$ & $2.67 \mathrm{~cd}$ & $6.14 c$ & $3.62 b c$ \\
\hline & & 60 & $2.41 \mathrm{bc}$ & $1.86 \mathrm{bc}$ & $4.28 b$ & $2.50 \mathrm{~b}$ \\
\hline & & 80 & $1.54 b$ & $1.21 \mathrm{ab}$ & $3.43 b$ & $2.19 b$ \\
\hline
\end{tabular}

scored the maximum yield increment (155.17\%) after healthy plant yield increment (185.06\%).

\section{Discussion}

Allelopathy is one of the modern applied strategies for controlling weeds which aim to minimize the use of chemical herbicides. Allelopathy phenomenon depends on the biochemical interaction between plants (Cheng and Cheng 2016). The results in Table 1 revealed the presence of GSLs $(9.55 \mu \mathrm{mol} / \mathrm{g} \mathrm{DW})$ and phenolic compounds $(46.5 \mathrm{mg} / \mathrm{g} \mathrm{DW})$ in E. sativa shoot powder which could be responsible for the allelopathic inhibitory effect on both weeds under investigation. Many researchers such as Messiha et al. 2013, Ahmed et al. 2014, and El-Dabaa et al. 2019 attributed the reduction in dry weight of weeds to the allelopathic effect of GSLs or phenolic compounds in E. sativa seed powder. Al-qasomi et al. 2009 revealed that E. sativa and other Brassica vegetables contain GSLs compounds which exert an antioxidant activity. Bell and Wagstaff (2014) ensured that 12 GLS compounds were identified in $E$. sativa. Additionally, 4-mercaptobutyl GSL (glucosativin), 4-methylthiobutyl GSL (glucoerucin), and 4-methyl sulfinylbutyl GSL (glucoraphanin) are the most abundant GSLs in E. sativa. These GSLs are hydrolyzed by myrosinase enzyme to create isothiocyanates, nitriles, thiocyanates, epithionitriles, indoles, oxazolidine-2-thiones, ascorbigens, goitrogens, cyanopithioalkanes, epithioalkanes, and flavonols (Hecht 1999; Bones and Rossiter 2006; Bell and Wagstaff 2014). Isothiocyanates is the main produced phytotoxic compound which achieved good results in weed management strategy (Ebrahimi et

Table 3 Effect of spraying different concentrations of E. sativa fresh aqueous extract on growth parameters of $P$. sativum plants. (Combined analysis of the two seasons)

\begin{tabular}{|c|c|c|c|c|c|c|c|c|c|c|}
\hline \multirow[t]{2}{*}{ Treatments } & \multirow{2}{*}{\multicolumn{2}{|c|}{$\begin{array}{l}\text { E. sativa fresh } \\
\text { aqueous } \\
\text { extract } \\
\text { concentration } \\
(\%)\end{array}$}} & \multicolumn{4}{|c|}{ First sample } & \multicolumn{4}{|c|}{ Second sample } \\
\hline & & & $\begin{array}{l}\text { Shoot } \\
\text { height } \\
(\mathrm{cm})\end{array}$ & $\begin{array}{l}\text { No. of } \\
\text { leaves/ } \\
\text { plant }\end{array}$ & $\begin{array}{l}\text { No. of } \\
\text { branches } \\
\text { /plant }\end{array}$ & $\begin{array}{l}\text { Dry weight } \\
\text { of plant }(\mathrm{g})\end{array}$ & $\begin{array}{l}\text { Shoot } \\
\text { height } \\
(\mathrm{cm})\end{array}$ & $\begin{array}{l}\text { No. of } \\
\text { leaves/ } \\
\text { plant }\end{array}$ & $\begin{array}{l}\text { No. of } \\
\text { branches/ } \\
\text { plant }\end{array}$ & $\begin{array}{l}\text { Dry weight } \\
\text { of plant (g) }\end{array}$ \\
\hline P. sativum only & 0 & & $34.0 \mathrm{a}$ & $18 \mathrm{a}$ & $1.4 \mathrm{a}$ & 1.93 a & 58.0 a & $24 a$ & $1.6 \mathrm{a}$ & $5.43 \mathrm{a}$ \\
\hline $\begin{array}{l}P . \text { sativum }+P . \text { minor }+B \text {. } \\
\text { vulgaris }\end{array}$ & 0 & & $20.0 \mathrm{e}$ & $13 d$ & $1.0 \mathrm{a}$ & $0.91 \mathrm{e}$ & $31.0 \mathrm{~g}$ & $16 \mathrm{~b}$ & $1.1 \mathrm{~b}$ & $1.62 \mathrm{~h}$ \\
\hline \multirow{4}{*}{$\begin{array}{l}P . \text { sativum }+P . \text { minor }+B . \\
\text { vulgaris }+E . \text { sativa }\end{array}$} & \multirow{4}{*}{$\begin{array}{l}\text { Once } \\
\text { spray }\end{array}$} & 20 & $22.0 \mathrm{e}$ & $15 a b$ & $1.0 \mathrm{a}$ & $1.16 \mathrm{~d}$ & $36.7 f$ & $22 \mathrm{a}$ & $1.2 \mathrm{~b}$ & $2.43 \mathrm{~g}$ \\
\hline & & 40 & $23.0 \mathrm{de}$ & $14 \mathrm{~cd}$ & $1.0 \mathrm{a}$ & $1.38 c$ & $42.0 \mathrm{e}$ & $22 \mathrm{a}$ & $1.2 \mathrm{~b}$ & $2.95 \mathrm{f}$ \\
\hline & & 60 & $27.3 \mathrm{c}$ & $16 a b$ & $1.0 \mathrm{a}$ & $1.49 \mathrm{C}$ & 46.5 de & $22 \mathrm{a}$ & $1.2 \mathrm{~b}$ & $3.25 \mathrm{ef}$ \\
\hline & & 80 & $29.5 b c$ & $16 a b$ & $1.3 \mathrm{a}$ & $1.67 b$ & $50.2 b c$ & $22 \mathrm{a}$ & $1.3 \mathrm{ab}$ & $4.11 \mathrm{~d}$ \\
\hline \multirow{4}{*}{$\begin{array}{l}P . \text { sativum }+P . \text { minor }+B . \\
\text { vulgaris }+E . \text { sativa }\end{array}$} & \multirow{4}{*}{$\begin{array}{l}\text { Twice } \\
\text { spray }\end{array}$} & 20 & $26.5 \mathrm{~cd}$ & $16 a b$ & $1.1 \mathrm{a}$ & $1.42 \mathrm{C}$ & 45.5 de & $22 \mathrm{a}$ & $1.2 \mathrm{ab}$ & $3.20 \mathrm{ef}$ \\
\hline & & 40 & $28.0 \mathrm{bc}$ & $16 a b$ & $1.2 \mathrm{a}$ & $1.52 b c$ & $48.8 \mathrm{~cd}$ & $22 \mathrm{a}$ & $1.3 \mathrm{ab}$ & $3.34 \mathrm{e}$ \\
\hline & & 60 & $30.0 \mathrm{bc}$ & $17 a b$ & $1.3 \mathrm{a}$ & $1.90 \mathrm{a}$ & $52.5 \mathrm{bc}$ & $22 \mathrm{a}$ & $1.4 \mathrm{ab}$ & $4.57 \mathrm{C}$ \\
\hline & & 80 & $31.5 \mathrm{ab}$ & $17 a b$ & $1.3 \mathrm{a}$ & $1.91 \mathrm{a}$ & $54.8 \mathrm{ab}$ & $24 \mathrm{a}$ & $1.4 \mathrm{ab}$ & $4.89 b$ \\
\hline
\end{tabular}


Table 4 Effect of spraying different concentrations of E. sativa fresh aqueous extract on yield and it's attributes of $P$. sativum plants. (Combined analysis of the two seasons)

\begin{tabular}{|c|c|c|c|c|c|c|c|}
\hline Treatments & \multicolumn{2}{|c|}{$\begin{array}{l}\text { E. sativa fresh } \\
\text { aqueous } \\
\text { extract } \\
\text { concentration } \\
(\%) \\
\end{array}$} & $\begin{array}{l}\text { No. of pods/ } \\
\text { plant }\end{array}$ & $\begin{array}{l}\text { Dry weight of pods/ } \\
\text { plant }(\mathrm{g})\end{array}$ & $\begin{array}{l}\text { No. of seeds/ } \\
\text { plant }\end{array}$ & $\begin{array}{l}\text { Dry weight of seeds/ } \\
\text { plant }(\mathrm{g})\end{array}$ & $\begin{array}{l}\% \text { of yield } \\
\text { increment /plant }\end{array}$ \\
\hline P. sativum only & \multicolumn{2}{|l|}{0} & $5.60 \mathrm{a}$ & $2.81 \mathrm{a}$ & $11.0 \mathrm{a}$ & $2.48 \mathrm{a}$ & 185.06 \\
\hline $\begin{array}{l}P . \text { sativum }+P . \text { minor }+B . \\
\text { vulgaris }\end{array}$ & \multicolumn{2}{|l|}{0} & $2.80 \mathrm{e}$ & $0.99 \mathrm{i}$ & $5.0 \mathrm{e}$ & $0.87 \mathrm{~h}$ & 0.00 \\
\hline \multirow{4}{*}{$\begin{array}{l}\text { P. sativum + P. minor + B. } \\
\text { vulgaris + E. sativa }\end{array}$} & \multirow{4}{*}{$\begin{array}{l}\text { Once } \\
\text { spray }\end{array}$} & 20 & 3.50 de & $1.35 \mathrm{~h}$ & $5.97 \mathrm{de}$ & $1.53 \mathrm{~g}$ & 75.86 \\
\hline & & 40 & $3.84 \mathrm{~cd}$ & $1.43 \mathrm{gh}$ & $6.47 \mathrm{de}$ & $1.58 \mathrm{fg}$ & 81.61 \\
\hline & & 60 & $3.95 b c$ & $1.65 f$ & $7.58 \mathrm{bc}$ & $1.83 \mathrm{e}$ & 110.35 \\
\hline & & 80 & $4.20 \mathrm{bc}$ & $1.91 \mathrm{~d}$ & $8.1 \mathrm{bc}$ & $2.04 \mathrm{~cd}$ & 134.48 \\
\hline \multirow{4}{*}{$\begin{array}{l}P . \text { sativum }+P . \text { minor }+B . \\
\text { vulgaris }+E \text {. sativa }\end{array}$} & \multirow{4}{*}{$\begin{array}{l}\text { Twice } \\
\text { spray }\end{array}$} & 20 & $3.84 \mathrm{~cd}$ & $1.53 \mathrm{~g}$ & $7.0 \mathrm{~cd}$ & $1.67 \mathrm{f}$ & 91.95 \\
\hline & & 40 & $4.68 \mathrm{ab}$ & $1.79 \mathrm{e}$ & $7.7 b c$ & $1.98 \mathrm{~d}$ & 127.59 \\
\hline & & 60 & $4.87 \mathrm{ab}$ & $2.37 c$ & $9.0 \mathrm{bc}$ & $2.13 b c$ & 144.83 \\
\hline & & 80 & $5.21 \mathrm{a}$ & $2.62 \mathrm{~b}$ & $9.4 a b$ & $2.22 \mathrm{~b}$ & 155.17 \\
\hline
\end{tabular}

al. 2011; Cerdeira et al. 2012; Messiha et al. 2013; Ahmed et al. 2014; El-Masry et al. 2015; Salim et al. 2017; Salisbury et al. 2018). Erucin and sativin compounds are the most biologically active isothiocyanate in E. sativa (Bennett et al. 2007). Also, in medicine, erucin and erysolin compounds have medicinal and therapeutic properties in E. sativa extract (Lamy et al. 2008). Hanafi et al. 2010 attributed the antifungal activity of $E$. sativa to the presence of antioxidant constituents: glucosinolate, flavonoids, carotenoids, and volatile oils. Moreover, E. sativa leaves contain kaempferol, quercetin, and isorhamnetin-3,4-diglucoside derivatives as a major group of phenolics. Kaempferol representing 77\%-88\% of total phenolics is followed by quercetin and isorhamnetin-3,4-diglucoside, representing $9 \%$ and $16.3 \%$ of the total phenolics, respectively (Weckerle et al. 2001; Pasini et al. 2011).

All these allelochemicals directly affect the physiological processes of plant, i.e., mitotic activity, photosynthesis, nutrient uptake, permeability of cell membrane, and respiration as well as enzyme activity inhibition and protein formation (Rice 1984; Wu et al. 2000; Xuan et al. 2004). Allelochemicals also affect photosynthetic area or assimilation rate which may be in turn cause plant dry matter reduction (Dadkhah 2012). As shown in Table 1, E. sativa fresh shoot aqueous extract negatively affected the dry weight of both weeds and this reduction increased by increasing concentration. These findings are in agreement with Hegab et al. (2008) who ensured the direct relationship between the high response to the inhibitory effect of the applied allelopathic extract and the increment in allelochemicals concentration. Additionally, twice spray of the extract was more effective than once and this in accordance with El-Wakeel (2015).
So, the twice spay of E. sativa water extract at the highest concentration (80\%) achieved the maximum reduction in weeds dry weight.

Tables 2 and 3 show that $P$. sativum growth and yield traits are increased by spraying $E$. sativa water extract. A direct relationship was observed between the concentration of the extract and the positive response of $P$. sativum plants. So, the twice spay of E. sativa water extract at the highest concentration $(80 \%)$ scored the highest $P$. sativum growth and yield parameters and also may be related to reduction of weed competition with $P$. sativum plants as recorded by several researchers (Bakht et al. 2009; El-Rokiek and Saad El-Din 2017; El-Rokiek et al. 2018). To this date, few studies have been carried out using the plant material of E. sativa to be used as a bioherbicide. Further studies must be explored on the mechanical action of these allelopathic compounds in controlling weeds and is hoped to be applied in the future as a source for natural herbicides under field conditions.

\section{Conclusion}

The presence of allelochemicals either GSLs or phenolic compounds in E. sativa fresh aqueous extract can be applied as a natural selective bioherbicide to control $P$. minor grassy weed and B. vulgaris broad-leaved weed infecting $P$. sativum crop. Twice spray of $80 \%$ fresh shoot aqueous extract was the most effective treatment in controlling both weeds under investigation. The efficiency of $80 \%$ fresh shoot aqueous extract in controlling weeds reflected in turn on $P$. sativum plants scoring the maximum yield traits following healthy treatment. So, $80 \%$ fresh shoot aqueous extract can be tested under field condition as a natural selective bioherbicide. 


\section{Abbreviations}

B. vulgaris: Beta vulgaris; DAS: Days after sowing; E. sativa: Eruca sativa: GSLS: Glucosinolates; P. minor: Phalaris minor; P. sativum: Pisum sativum

\section{Acknowledgements}

This research was supported by the project of National Research Centre" (Egypt)" Some safe strategies to improve weed control efficiency in some export crops" (No11040202).

\section{Funding}

This work was supported and funded by National Research Centre through the project entitled: (Some safe strategies to improve weed control efficiency in some export crops). Project No. (11040202), during in-house projects strategy 2016-2019.

\section{Availability of data and materials}

The datasets generated during and/or analyzed during the current study are included in this published.

\section{Authors' contributions}

All authors share in every step of this work, and all of them contribute in writing the manuscript. All authors read and approved the final manuscript.

\section{Authors' information}

Dr. Mona Adel El-Wakeel is a researcher at the National Research Centre, Dokki, Giza, Botany Department; Agicultural and Biological Division. Prof. Dr. Ebrahim Roushdi El-Desoki is a professor at the National Research Centre, Dokki, Giza, Botany Department; Agicultural and Biological Division. Salah El-Din Abd El-Ghany Ahmed is a professor at National Research Centre, Dokki, Giza, Botany Department; Agicultural and Biological Division.

\section{Ethics approval and consent to participate}

Not applicable.

\section{Consent for publication}

Not applicable.

\section{Competing interests}

The authors declare that they have no competing interests.

\section{Publisher's Note}

Springer Nature remains neutral with regard to jurisdictional claims in published maps and institutional affiliations.

\section{Received: 26 March 2019 Accepted: 10 May 2019}

Published online: 06 June 2019

\section{References}

Ahmed SA, El-Rokiek KG, El-Masry RR, Messiha NK (2014) The efficiency of Allelochemicals in the seed powder of Eruca sativa in controlling weeds in Pisum sativum. Middle East J Agric Res 3(4):757-762

Al-qasomi S, Al-sohaibani M, Al-Howriny T, Al-Yahya M, Rafatullah S (2009) Rocket (Eruca sativa): a salad herb with potential gastric anti-ulcer activity. World J Gastroenterol 15(6):1958-1965. https://doi.org/10.3748/wjg.15.1958

Bakht T, Khan IA, Khan MI, Khan I, Khattak AM (2009) Weed control in pea (Pisum sativum L.) through mulching. Pak J Weed Sci Res 15(1):83-89

Bell L, Wagstaff C (2014) Glucosinolates, Myrosinase hydrolysis products, and flavonols found in rocket (Eruca sativa and Diplotaxis tenuifolia). J Agric Food Chem 60(2):4481-4492 https:/pubs.acs.org/doi/abs/10.1021/jf501096x

Bennett RN, Carvalho R, Mellon FA, Eagles J, Rosa EAS (2007) Identification and quantification of glucosinolates in sprouts derived from seeds of wild Eruca sativa L. (salad rocket) and Diplotaxistenuifolia L. (wild rocket) from diverse geographical locations. J Agric Food Chem 55:67-74 https://pubs.acs.org/ doi/abs/10.1021/jf061997d

Bennett RN, Mellon FA, Botting NP, Eagles J, Rosa EAS, Williamson G (2002) Identification of the major glucosinolate (4-mercaptobutylglucosinolate) in leaves of Eruca sativa L. Phytochem 61:25-30. https://doi.org/10.1016/S00319422(02)00203-0

Bennett RN, Rosa EAS, Mellon FA, Kroon PA (2006) Ontogenic profiling of glucosinolates, flavonoids, and other secondary metabolites in Eruca sativa (salad rocket), Diplotaxiserucoides (wall rocket), Diplotaxistenuifolia (wild rocket) and Bunias orientalis (Turkish rocket). J Agric Food Chem 54:40054015. https://doi.org/10.1021/jf052756t

Bones AM, Rossiter JT (2006) The enzymic and chemically induced decomposition of glucosinolates. Phytochem 67:1053-1067. https://doi.org/ 10.1016/j.phytochem.2006.02.024

Bonnessen C, Eggleston IM, Hayes JD (2001) Dietary indoles and isothiocyanates that are generated from cruciferous vegetables can both stimulate apoptosis and confer protection against DNA damage in human colon cell lines. Cancer Res 61:6120-6130

Cerdeira AL, Cantrell CL, Dayan FE, Byrd JD, Duke SO (2012) Tabanone, a new phytotoxic constituent of cogongrass (Imperatacylindrica). Weed Sci 60:212218. https://doi.org/10.1614/WS-D-11-00160.1

Cheng F, Cheng Z (2016) Corrigendum: research progress on the use of plant allelopathy in agriculture and the physiological and ecological mechanisms of allelopathy. Front Plant Sci 7(1697):1-16. https://doi.org/10.3389/fpls.2016.01697

Dadkhah A (2012) Phytotoxic effect of aqueous extract of eucalyptus sunflower and sugerbeet on seed germination, growth and photosynthesis of Amaranthus retrofelexus. Allelopath J 29(2):287-296

Daxenbichler ME, Spencer GF, Carlson DG, Rose GB, Brinker AM, Powell RG (1991) Glucosinolate composition of seeds from 297 species of wild plants. Phytochem 30:2623-2638. https://doi.org/10.1016/0031-9422(91)85112-D

Duncan DB (1955) Multiple range and multiple F. tests. Bimetrics 11:1-42

Ebrahimi F, Hosseini NM, Hosseini MB (2011) Effects of herbal extracts on red root pigweed ( Amaranthus retroflexus) and lambs quarters (Chenopodium album) weeds in pinto 143 bean (Phaseolus vulgaris). Iran J Field Crop Sci 42: 757-766

El-Dabaa MAT, Ahmed SA, Messiha NK, El-Masry RR (2019) The allelopathic efficiency of Eruca sativa seed powder in controlling Orobanche crenata infected Vicia faba cultivars. Bull Natl Res Cent 43(37):1-8. https://doi.org/10. 1186/s42269-019-0079-9

El-Masry RR, Messiha NK, El-Rokiek KG, Ahmed SA, Mohamed SA (2015) The allelopathic effect of Eruca sativa Mill. Seed powder on growth and yield of Phaseolus vulgaris and associated weeds. Curr Sci Int 4(4):485-490

El-Rokiek KG, Saad El-Din SA (2017) Allelopathic activity of Eucalyptus globulus leaf water extract on Pisum sativum growth, yield and associated weeds. Middle East J Appl Sci 7(4):907-913

El-Rokiek KG, Saad El-Din SA, El-Wakeel MA, Dawood MG, El-Awadi M (2018) Allelopathic effect of the two medicinal plants Plectranthus amboinicus (Lour.) and Ocimum basilicum L. on the growth of Pisum sativum L. and associated weeds. Middle East J Agric Res 7(3):1146-1153

El-Wakeel MA (2015) Effect of allelopathy and autotoxicity of some plants as well as herbicides on wheat and associated weeds PHD. Thesis, Faculty of Science, Benha University, Egypt

Fahey JW, Zalcmann AT, Talalay P (2001) The chemical diversity and distribution of glucosinolates and isothiocyanates among plants. Phytochem 56:5-51. https://doi.org/10.1016/S0031-9422(00)00316-2

Ferreira AG, Áquila MEA (2000) Alellopathy: an emerging topic in ecophysiology. Rev Bras Fisiol Veg 12:175-204

Fuentes E, Castro R, Astudillo L, Carrasco G, Alarcón M, Gutierrez M, Palomo (2012) Bioassay-guided isolation and HPLC determination of bioactive compound that relate to the anti-platelet activity (adhesion, secretion and aggregation) from Solanum lycopersicum. Evid Based Complement Alternat Med 147031:1-10. https://doi.org/10.1155/2012/147031

Hanafi EM, Hegazy EM, Riad RM, Amer HA (2010) Bio-protective effect of Eruca sativa seed oil against the hazardus effect of aflatoxin $B 1$ in male rabbits. Int J Acad Res 2(2):67-74

Hecht SS (1999) Chemoprevention of cancer by isothiocyanates, modifiers of carcinogen metabolism. J Nutr 129(3):768S-774S. https:/doi.org/10.1093/jn/129.3.768S

Hegab MM, Khodary SEA, Hammouda O, Gharieb HR (2008) Autotoxicity of chard and its alllopathic potentiality on germination and some metabolic activities associated with growth of weed seedling. Afr J Biotechnol 7:884-892

Jabran K, Mahajan G, Sardana V, Chauhan BS (2015) Allelopathy for weed control in agricultural systems. Crop Prot 72:57-65. https://doi.org/10.1016/j.cropro. 2015.03.004

Khan TD, Elzaawely AA, Chung IM, Ahn JK, Tawata S, Xuan TD (2007) Role of allelochemical for weed management in rice. Allelopath J 19:85-96

Lamy E, Shoder J, Paulus S, Brenk P, Stahi T, Sandermann VM (2008) Antigeno- toxic proprieties of Eruca sativa (Rocket plant), erocin and erysolin in human hepatoma (HePG2) cells towards benzo(a) pyrene and their mode of action. Food Chem Toxicol 46(7):2415-24210. https://doi. org/10.1016/j.fct.2008.03.022 
Martinez-Ballesta M, Moreno DA, Carvajal M (2013) The physiological importance of glucosinolates on plant response to abiotic stress in Brassica. Int J Mol Sci 14(6):11607-11625. https://doi.org/10.3390/ijms140611607

Martinez-Sanchez A, Gil--zquierdo A, Gil MI, Ferreres F (2008) A comparative study of flavonoid compounds, vitamin $C$ and antioxidant properties of baby leaf Brassicaceae species. J Agric Food Chem 56:2330-2340. https://doi.org/10. 1021/jf072975+

Messiha NK, Ahmed SA, El-Rokiek KG, Dawood MG, El-Masry RR (2013) The physiological influence of allelochemicals in two Brassicaceae plant seeds on the growth and propagative capacity of Cyperusrotundus and Zea mays L. World Appl Sci J 26(9):1142-1149. https://doi.org/10.5829/idosi.wasj.2013.26. 09.13548

Nasirullah, Krishnamurthy MN (1996) Amethod for estimating glucosinolates in mustard/rapeseeds and cake. J Food Sci Technol 33(6):498-450

Oerke EC (2006) Crop losses to pests. J Agric Sci 144:31-43. https://doi.org/10. 1017/50021859605005708

Ori R, Bernardi R, Gueyrard D, Rollin P, Palmieri S (1999) Formation of glucoraphanin by chemoselective oxidation of natural glucoerucin: a chemoenzymatic route to sulphoraphane. Bioorg Med Chem Lett 9:10471048. https://doi.org/10.1016/S0960-894X(99)00136-5

Pasini F, Verardo V, Cerretani L, Caboni MF, D'Antuono LF (2011) Rocket salad (Diplotaxis and Eruca spp.) sensory analysis and relation with glucosinolate and phenolic content. J Sci Food Agric 91:2858-2864. https://doi.org/10. $1002 /$ jffa. 4535

Rauchberger Y, Mokady S, Cogan U (1979) The effect of aqueous leaching of glucosinolates on the nutritive quality of rapeseed meal. J Sci Food Agric 30: 31-39. https://doi.org/10.1002/jsfa.2740300107

Reigosa MJ, Pedrol N, González L (2006) Allelopathy - a physiological process with ecological implications. Springer, Berlin, p 637

Rice EL (1984) Allelopathy, 2nd edn. Academic press, New Yourk, p 424

Salim HA, Abdalbaki AA, Khalid HA, Eshak HS, Reski B, Alwan WK (2017) Allelopathic effects for three plants extracts on weeds of wheat (Triticum aestivum L.). J Medi Herbs Ethnomedicine 3:31-33. https://doi.org/10.25081/ jmhe.2017.v3.338

Salisbury PA, Potter TD, Gurung AM, Mailer RJ, Williams WM (2018) Potential impact of weedy Brassicaceae species on oil and meal quality of oil seed rape (canola) in Australia. Weed Res 58(3):200-209. https://doi.org/10.1111/ wre. 12296

Smith TJ (2001) Mechanisms of carcinogenesis inhibition by isothiocyanates. Expert Opin Investig Drugs 10:2167-2174. https://doi.org/10.1517/13543784. 10.12.2167

Snedecor GW, Cochran WG (1980) Statistical methods, 7th edn. lowa State University press, Ames

Snell FD, Snell CT (1953) Colorimetric methods, vol 111. Organic, D. Van Nostrand Company, Inc, Toronto, New York, London, p 66

Villatoro-Pulido M, Font R, Saha S, Obregon-Cano S, Anter J, Munoz-SerranoDe A Haro-Bailon A, Alonso-Moraga A, Del Rio-Celestino M (2012) In vivo biological activity of rocket extracts (Eruca vesicaria subsp. sativa (Miller) Thell) and sulforaphane. Food Chem Toxicol 50:1384-1392

Vyyyan JR (2002) Allelochemicals as leads for new herbicides and agrochemicals. Tetrahedron 58:1631-1636

Weckerle B, Michel K, Balazs B, Schreier P, Toth G (2001) Quercetin 3,3',4'-tri-O-be ta-D-glucopyranosides from leaves of Eruca sativa (Mill.). Phytochemistry 57: 547-551. https://doi.org/10.1016/S0031-9422(01)00059-0

Wu H, Pratley J, Lemerle D, Haig T (2000) Laboratory screening for allelopathic potential of wheat (Triticum aestivum) accessions against annual rye grass. Aust J Agric Res 51(2):259-266. https://doi.org/10.1071/AR98183

Xuan TD, Eiji T, Khan TD (2004) Methods to determine allelopathic potential of crop for weed control. Allelopath J 13(2):149-164

Zhang Y (2004) Cancer-preventive isothiocyanates: measurement of human exposure and mechanism of action. Mutat Res 555:173-190. https://doi.org/ 10.1016/j.mrfmmm.2004.04.017

\section{Submit your manuscript to a SpringerOpen ${ }^{\circ}$ journal and benefit from:}

- Convenient online submission

- Rigorous peer review

- Open access: articles freely available online

High visibility within the field

- Retaining the copyright to your article

Submit your next manuscript at $\boldsymbol{\nabla}$ springeropen.com 